\title{
FIRST RECORD OF A FOSSIL CHITON (POLYPLACOPHORA) FROM THE BOHEMIAN CRETACEOUS BASIN (LATE CRETACEOUS)
}

\author{
Jaroslav Marek, Martin Košták*, Martin Mazuch \& Oldřich Karoušek
}

Charles University in Prague, Faculty of Science, Institute of Geology and Palaeontology, Albertov 6, Praha 2, 128 43, Czech Republic; emails: marekj@ natur.cuni.cz,martin.kostak@natur.cuni.cz,mmazuch@ natur.cuni.cz

* corresponding author

\begin{abstract}
The first record of a chiton (Polyplacophora) from the Bohemian Cretaceous Basin (Late Cretaceous) is described herein. It comes from the working quarry of Plañany, located near the town Kolin. Excavated deposits are of the late Cenomanian - early Turonian. The poorly preserved specimen consists of a tail valve remain and two intermediate valves, it is associated herein only with order level - i.e. Lepidopleurida Thiele, 1910. The state of its preservation shows signs of corrosion of dorsal part caused probably by biologic digestion (in stomach) and/or, more probably, by long exposure at the sea bottom. Stratigraphically, the layer yielding chiton shell is referred to be the late Cenomanian in age. The chiton living conditions are interpreted as very shallow water environment (not exceeding $20 \mathrm{~m}$ ) with irregular rocky basement possessing numerous caves and crevices.
\end{abstract}

Key words: Polyplacophora, ?Lepidopleurida, Upper Cretaceous, late Cenomanian - Turonian interval, Bohemian Cretaceous Basin, Czech Republic.

\section{INTRODUCTION}

The Mesozoic record of fossil chitons is (compared e.g. that of Carboniferous and late Tertiary) rather scarce. The contemporary summary of fossil chiton records from the last century has been given by Smith $(1960,1973)$, Sirenko et Starobogatov (1977) and Ziegler (1991, fig. 205, p. 187), particular records are described by numerous authors (i.e. Bergenhayn 1946, 1955; Berry 1939; Parona 1909; Quenstedt 1932; Sirenko 2013; Smith et al 1968; etc.). Recently, new and more complete list of all known living and fossil chitons is given by Schwabe (2005, see also for more additional citations). According to Ziegler (1991), the Mesozoic chitons are more frequent in generic level predominantly in the Jurassic and they are reported to be rarer in the Triassic and Cretaceous (ca in ratio 16:6:7 for relevant taxa - 16 Jurassic; 6 Triassic, 7 Cretaceous). Disproportions in stratigraphic occurrences of the Paleo-, Meso- and Cenozoic records were also discussed by Puchalski et al. (2008). The reason of this disproportion (in particular the comparison with the Upper Palaeozoic) are probably as follows:
1) Isolated valves of polyplacophorans are small and inconspicious, thus they are consenquently overlooked and not collected.

2) Sediments from milieu where chitons proliferate (very shallow water sediments) are seldom preserved in sedimentary record (e.g. relatively common finds of chitons from Carboniferous and Permian are related to the slided down shallow water sediments - e.g. turbidites).

3) Character of the most of sediments in the environment usually dwelled by chitons is not favourable for preservation of chitons.

4) Mesozoic and especially the Cretaceous chitons were less abundant in ecosystems.

The reasons mentioned above are those why the discovery of chiton fragment from the Upper Cretaceous of the Czech Republic described herein are exceptional (regardless its bad preservation) even if more than 150 years of fossil hunting in the area. Actually, it is the first record of a chiton from the Bohemian Cretaceous Basin (BCB) and the Central European Late Cretaceous shallow water basins as a whole. The only one previous (and 
commonly cited) record of the Cretaceous „chiton“ comes from the Western Carpathians in the eastern part of the Czech Republic (Plička 1981 - Chiton beskydensis from the Moravsko- slezské Beskydy Mts., Northern Moravia) does not represent a chiton. Our investigation confirmed that it is an imprint of a smaller amonite shell with coarse ribs. It can be compared with similar imprints known especially from the Solnhofen (Germany) from the Upper Jurasic lithographic limestones for example see Müller (1979, figs 13 and 14 B, p. 20-21). Therefore, Plička s (1981) material represents a misleading determination of a Chiton and Ch. beskydensis has to be excluded from the lists of fossil chiton.

\section{GEOLOGIC SETTING AND STRATIGRAPHY}

The studied fossil remain of chiton has been recently found in the Plaňany working quarry (about $45 \mathrm{~km}$ east of Prague) near Kolín town; (Figure 1), a locality in the southern margin of the Bohemian Cretaceous Basin (BCB). In this location, nearshore/shallow water sediments were deposited in depressions of the metamorphic basement (predominantly sillimanitic-biotitic migmatite, amfibolite, gneisses - Fišera, 1981; Ziegler, 1992; Novák and Vrbová, 1996). The large depressions comprise a basal Cenomanian conglomerate at the bottom overlain by the Cenomanian organodetritic sedi-

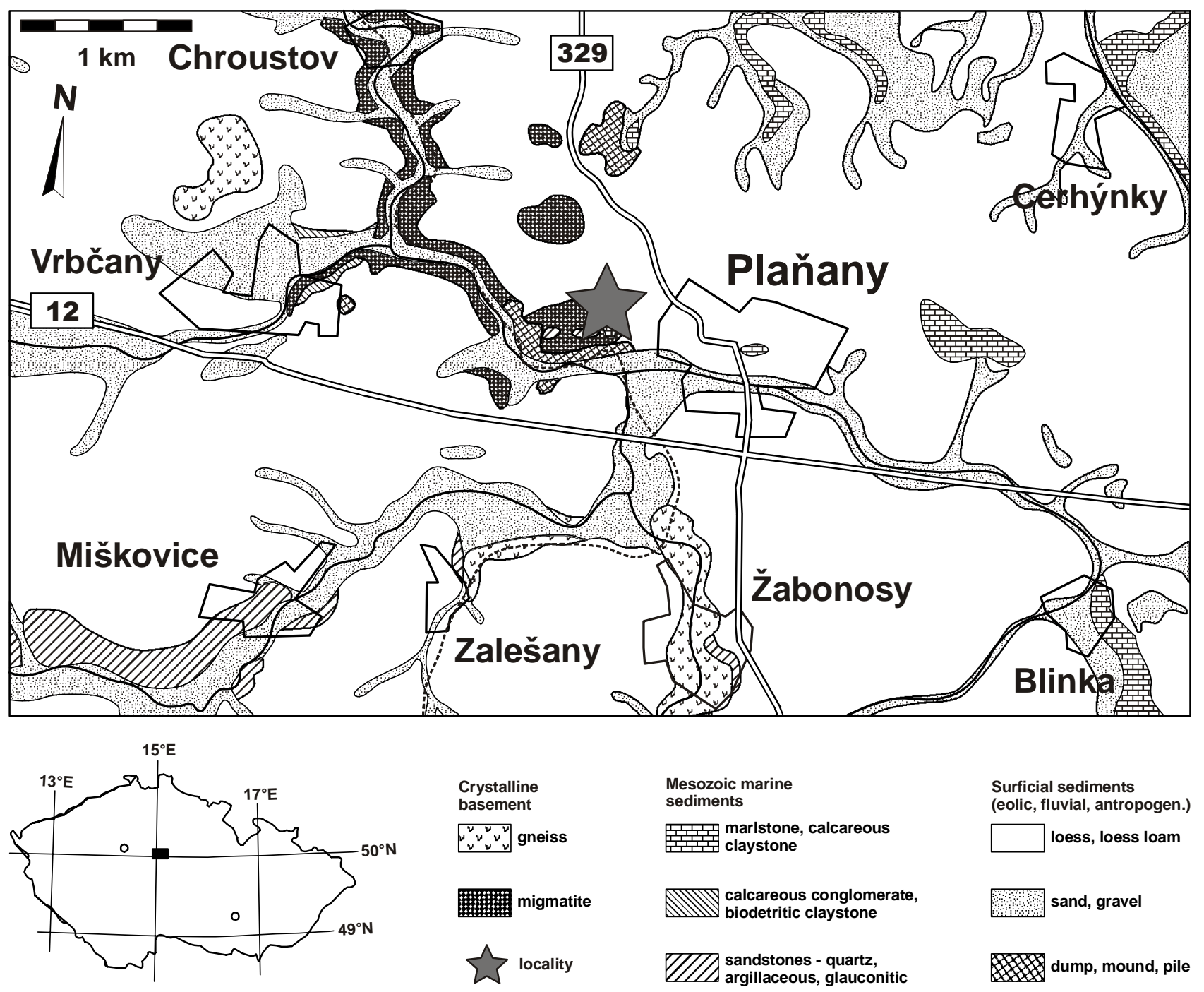

Figure 1. Geologic map and geographic position of the locality Plaňany (Czech Republic, Bohemian Cretaceous Basin). 
ment and redeposited Turonian conglomerate. The sedimentary unit is overlain by calcitic-clayey siltstones with organodetritic matter (Figure 2). The sedimentary succession continues higher up by marly siltstones with intercalations of richly fossiliferous phosphatized beds. Chiefly phosphatized invertebrate coprolithes and sponges are frequent.

The sediment which yielded chiton remnant is probably of the late Cenomanian in age even if basal sediments sitting just on the rocky basement contain both the Cenomanian and the Turonian fauna because of combination of sedimentary processes and aspects resulting into common erosional surfaces, frequent gaps (the two ammonite zones are missing at least in this critical interval) and faunal reworking (related also to bioturbated layers). The character of sedimentation was also influenced by palaeohydrodynamics, palaeotopography, clastic distribution, and character combined with abundance of detrital material (Žítt, 1992; Žitt and Nekvasilová, 1996). The sediment with chiton consist of organodetritic clayey limestone with the Cenomanian fauna (e.g. Amphidonte
(Ceratostreon) reticulata Reuss, Codiopsis doma (Desmarest). These beds are developed in the unusual facies reflecting cave condition with a fossil association dominating by echinoids Codiopsis doma (Desmarest), Pyrina desmoulinsi d'Archiac, Diadema sp., Pygastes sp., gastropod Neritopsis sp., and abundant echinoid spikes.

\section{SYSTEMATICS}

Class Polyplacophora Gray, 1821

Subclass Loricata Shumacher, 1817

Order Lepidopleurida Thiele, 1910 Family, gen. et sp. undet. - Plate I (Figs 1-7)

Material and locality. A single strongly abraded and/or corroded fragment of three associated valves (VI. and VII. intermediate valves and a part of the tail valve - Plate I, Figs 1, 3, 6 ). Temporarily deposited under No. IGP - 2010/1Pl in the Collections of the Institute of Geology and Palaeontology (Chlupáč's Museum of Earth History), Faculty of Science, Charles University in Prague.

$\mathbf{N}$

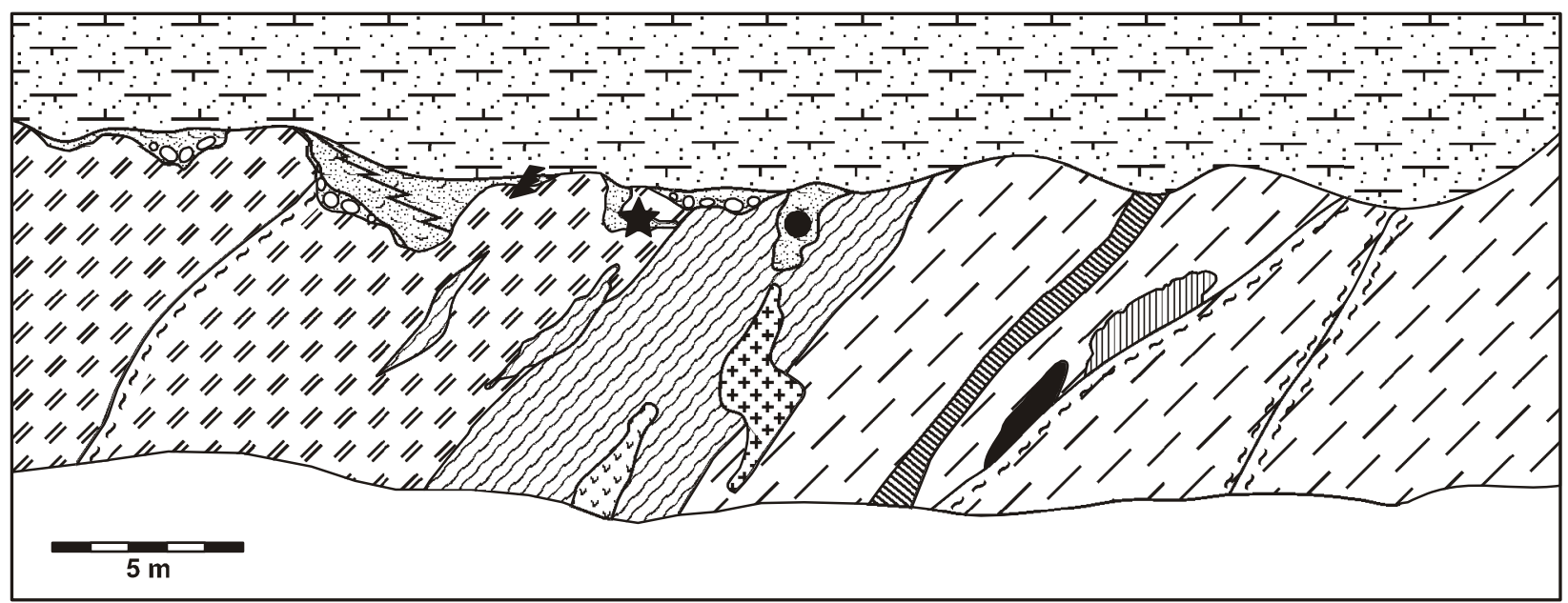

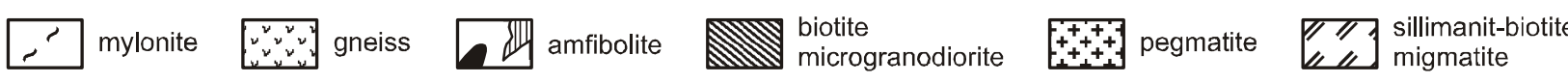

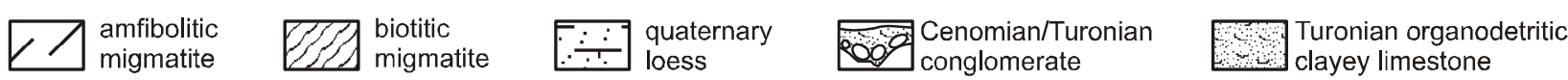

$\square$ codiopsis assemblage chiton find 5 reticulata assemblage

Figure 2. Geologic situation at the locality and the position of a chiton record (asterisk). Geologic sketch modified after Fišera (1981). 


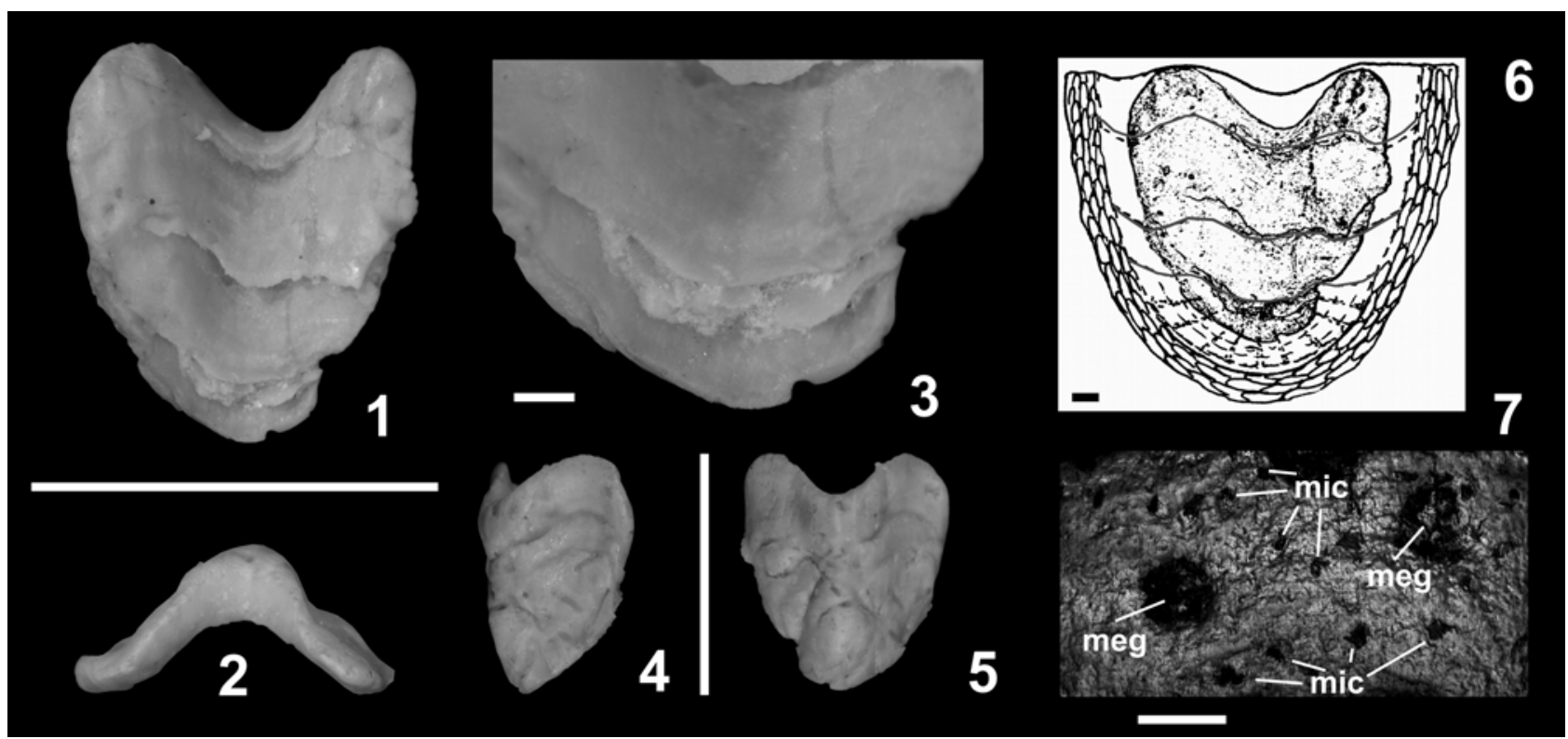

Plate I. Specimen No. IGP - 2010/1Pl. 1. Ventral view. 2. Cross-section. Scale bar for figs. 1- 2: $10 \mathrm{~mm}$. 3. Detail of the valve VII and ant partialy preserved tail valve. 4. Lateral view. 5. Dorsal view. Scale bar for figs. 4-5: 10 mm. 6. Reconstruction based on preserved part of valves. Scale bar $1 \mathrm{~mm}$. 7. SEM photo showing distribution of micra- and megalaesthetes.

Scale bar $40 \mu \mathrm{m}$. Abbreviations: meg: megalaesthete, mic: micraesthete

Czech Republic, Bohemian Cretaceous Basin, Upper Cretaceous, upper Cenomanian (upper Cenomanian - lower Turonian boundary interval). Working quarry at Plaňany near Kolín town.

Description. The specimen is $9.5 \mathrm{~mm}$ long (in the median line $8 \mathrm{~mm}$ long) and $8 \mathrm{~mm}$ wide, partly deformed fragment. It represents two intermediate valves (VI-VII) and the tail valve, which is incomplete with its sinistro-posterior margin irregulary bitten or broken out in a wide $\mathrm{V}$ shape. All three valves have strongly damaged surfaces. Original body outline can be inferred as probably elongateoval (Plate I, Fig. 6). The total length of the complete specimen can be estimated (reconstructed, supposed) for about $21 \mathrm{~mm}$ by comparison with Recent representatives of Chiton marmoratus Gmelin, which was selected based on similar valves proportion with that observed on the studied Cretaceous specimen.

Intermediate valves are rectangular with slightly inflated lateral areas. They are moderate long in the median line, their length equals about $35 \%$ (32 and $37 \%$ ) of their width. They are also moderate to highly carinated (the cross section angle exceeds $100^{\circ}$ - Plate I, Fig. 2). Its side slopes are slightly concave (may be secondary due to the surface digestion). Apophyses are broken off.
Tail valve is not complete with crushed marginal parts, however, it seems to be semicircular.

Periostracum is not preserved on valve surface. Tegmentum is poorly preserved and it is smooth, secondarily covered by carbonate glaze, and without any visible sculptures. Only part of the valve VI surface shows typical microstructures, described below, and few parallel fine ribs are slightly indicated. The whole dorsal side of the fragment is strongly corroded with only poorly visible to invisible demarcation lines between valves (Plate I, Figs 4 and 5). The surface shows signs typical for biochemical (probably in some fish stomach) and/ or, more likely, diagenetic corrosion. The dorsal surface is secondarily bored by epizoans. Thus, the morphological characters typical for the chiton dorsal part are almost completely destroyed. The only exception are the aesthete pores observed on the surface of the valve VI in the SEM (Plate I, Fig. 7). Megalaesthete are about $40 \mu \mathrm{m}$ in diameter (larger size sis supposed to be caused by strong tegmentum abrassion and exposure of larger cavity diameter). Micraesthetes are irregularly arranged (Plate I, Fig.7). The terminology used herein follows Schwabe (2010), Sigwart et al. (2007) and Sigwart (2009). 
Remarks. With respect to the very bad preservation of the studied chiton remain, it is not allowed neither to determine it more precisely (on the order taxonomical level, at least) nor to compare it with the other previous specimens of Cretaceous chitons and thus to discuss appropriatelly its morphological similarities as well as taxonomic relationships.

Stratigraphical range and geographical distribution. Bohemian Cretaceous Basin, Upper Cretaceous, upper Cenomanian, Peruc-Korycany Formation - Bílá Hora Formation boundary interval. Czech Republic, working quarry at Plaňany near Kolín town (approximately $45 \mathrm{~km}$ east of Prague).

\section{DISCUSSION}

Although, the sediments and fauna of the Bohemian Cretaceous Basin have systematically been studied more than 150 years, no chiton remnant has been recorded up to our discovery. This unique fossil represents also an exceptional record of the Cretaceous chitons in the Central European Cretaceous seas. Such rarity is probably caused not only by the taphonomic influences.

The finding place of the specimen was reconstructed as a small cave (or cavity - Fig. 2) in a crystallinite rock. However, the fragment is strongly corroded (or abraded), we suppose the hard-rock substrate with smaller caves to be an original habitat of the chitons in the BCB. Also numerous pockets and crevices are well known from the studied locality, forming suitable substrate for chitons, as comparable in Recent seas.

\section{CONCLUSIONS}

The chiton record proves the Late Cretaceous polyplacophoran existence in the Central European platform seas. Its occurrence in the near shore/ shallow water facies in relation to rocky substrate clearly documents similar living conditions to Recent shallow water chitons. The mode of life is supposed to be a facultative mobile epifaunal grazer on hard rock substrate. The sediment character as well as the palaeogeographic setting, proved by associated fauna, document a very shallow water environment, not exceeding 15-20 m depth. These bathymetric conditions combined with sea-bottom rocky surface are also suggested to be a true habitat of the chiton described herein. In Recent Lep- idopleurida, the depth range is reported from 1 to 4200m (Hyman, 1967), the maximum depth recorded is $7657 \mathrm{~m}$ (Sirenko, 1977).

\section{ACKNOWLEDGEMENT}

We are indebted to Mr. O. Karoušek for donation of chiton specimen. The Cretaceous research is partly supported by Project PRVOUK 44 . We thank to reviewers Boris Sirenko (Zoological Institute RAS, St. Petersburg) and Petr Kraft (Charles University Prague) for constructive comments and tutorials.

\section{REFERENCES}

Bergenhayn, J.R.M. 1943. Preliminary notes on fossil Polyplacophorans from Sweden. Geologiska Foereningen $i$ Stockholm Foerhand 65(3), 297-303.

Bergenhayn, J.R.M. 1955. Die fossilen schwedischen Loricaten nebst einer vorläufigen Revision des Systems der Ganze Klasse Loricata. Skrifter Från Mineralogisk- Och Paleontologisk-geologiska Institutionera Lund 22(8), 1-46.

Berry, C.T. 1939. Some fossil Amphineura from the Atlantic coastal plain of North America. Proceedings of the Academy of Natural Sciences of Philadelphia 91, 207-217.

Fišera, M. 1981. Geologické a petrografické poměry okolí Plaňan. Výzkumné práce ÚÚG 26 , $1-42$.

Gray, J.E. 1821. Natural arrangement of Mollusca according to their internal structure. London Medical Repository 15, 1- 234.

Hyman, L.H. 1967. The Invertebrates. Mollusca 1(6), 1-792. McGraw-Hill, New York.

Müller, A.H. 1979. Fossilization (Taphonomy). In Moore, R. C. (ed.): Treatise on invertebrate paleontology, A, Introduction: A2-A78. Geological Society of America et University Kansas Press, Lawrence.

Novák J.K., Vrbová H. 1996. Petrogenesis and geochemistry of mafic rocks from the Kutná hora Crystalline Complex and the neighbouring part of the Rataje Micaschist Zone. Geolines 4, 1-17.

Parona, C.F. 1909. La fauna coralligena del Cretaceo dei Monti d'Ocre nell'Abruzzo aquilano. Memorie per Servire alla Descrizione della Carta Geologica d'Italia 5, 1. 
Plička 1981. Chiton beskidensis n.sp. from the Upper Cretaceous (Upper Godula Beds) in the Moravskoslezské Beskydy (Mountains), Czechoslovakia. Zbornik geologických vied, Západné Karpaty, Séria Paleontológia 6, 26.

Puchalski, S.S., Eernisse, D., Johnson, C.C. 2008. The effect of sampling bias on the fossil record of chitons (Mollusca, Polyplacophora). American Malacological Bulletin 25, 87-95.

Quenstedt, W. 1932. Die Geschichte der Chitonen und ihre allgemeine Bedeutung. - Palaeontologische Zeitschtift 14, 77-96.

Schwabe, E. 2005. A catalogue of Recent and fossil chitons (Mollusca: Polyplacophora). Addenda. Novapex 6(4), 89-105.

Schwabe, E. 2010. Illustrated summary of chiton terminology (Mollusca, Polyplacophora). - Spixiana 33(2), 171-194.

Sigwart, J.D., Andersen, S.B., Schnetler K.I. 2007. First record of a fossil chiton from Denmark Polyplacophora: Leptochitonidae and its phylogenetic affinities. Journal of Systematic Palaeontology 5, 123-132.

Sigwart, J.D. 2009. The deep-sea chiton Nierstraszella (Mollusca: Polyplacophora: Lepidopleurida) in the West Pacific: taxonomy, morphology, and a bizarre ectosymbiont. Journal of Natural History 43(7-8), 447-468.

Sirenko, B.I. 1977. Vertical distribution of chitons of the genus Lepidopleurus (Lepidopleuridae) and its new ultraabyssal species. Zoologicheskij Zurnal 61, 1107-1110.

Sirenko, B.I. 2013. Four new species and one new genus of Jurassic chitons (Mollusca: Polypla- cophora: Lepidopleurida) from the Middle Russian Sea. Proceedings of the Zoological Institute of the Russian Academy of Scince 317(1), 30-44.

Sirenko, V.I., Starobogatov, J.I. 1977. K sistematike paleozojskich i mezozojskich chitonov. $P a-$ leontologicheskij Zhurnal 1977(3), 30-41.

Smith, A.G. 1960. Amphineura. In Moore, R.C. (ed.): Treatise on invertebrate paleontology, Pt. I, Mollusca 1: I41-I76. Geological Society of America et University Kansas Press, Lawrence.

Smith, A.G. 1973. Fossil chitons from the Mesozoic. A checklist and bibliography. Occasional papers of the California Academy of Sciences 103, 1-30. Smith, A., Sohl, N.F., Yochelson E.L. 1968. New Upper Cretaceous Amphineura (Mollusca). U.S. Geological Survey Professional Paper 593-G, 1-9.

Thiele, J. 1909. Revision des Systems der Chitonen. I. Teil. Zoologica 22(1), 1-70.

Ziegler, B. 1991. Einführung in die Paläobiologie. Teil 2. Spezielle Paläontologie. 409 pp.. E. Schweizerbart'sche Verlagsbuchhandlung, Stuttgart.

Ziegler, V. 1992. Stratigrafie a vrstevní sled křídových sedimentů v kolínské oblasti české křídové pánve. Časopis Národního muzea, $\check{R} a d a$ přirodovědná 160, 1(4), 29-46.

Žítt, J. 1992. Bored and mineralized limestone surfaces in the Upper Cretaceous of Bohemia. A preliminary report. Věstník Českého geologického ústavu 67(2), 109-115.

Žítt, J., Nekvasilová, O. 1996. Epibionts, their hard-rock substrates, and phosphogenesis during the Cenomanian-Turonian boundary interval (Bohemian Cretaceous Basin, Czech Republic). Cretaceous Research 17(6), 715-739. 